\title{
PHYSICAL PROPERTIES AND RATE OF DIFFUSION TRANSETHOSOME CURCUMIN USING A COMBINATION OF TWEEN 60 AND SPAN 60 AS SURFACTANT
}

\author{
ANISA AMALIA*, YUDI SRIFIANA, AMALIA ANWAR \\ Faculty Pharmacy and Sains, Universitas Muhammadiyah Prof. DR. Hamka, East Jakarta 13460, Indonesia \\ Email: anisa.amalia@uhamka.ac.id
}

Received: 30 Sep 2020, Revised and Accepted: 20 Oct 2020

\begin{abstract}
Objective: Curcumin penetration can be increased by formulating it into the transethosome system. Surfactant is one of the transethosome components that affect the physical properties and penetration of vesicles. In this study, a combination of two surfactants was used to see the effect
\end{abstract} of surfactants on physical properties and curcumin penetration.

Methods: This study used a combination of tween 60 and span 60 with a concentration ratio of 0:5 (F1), 1:1 (F2), 2:1 (F3), and 1:2 (F4). An evaluation included testing the distribution of particle size, zeta potential, and entrapment efficiency in the system. Evaluation continued with the determination of the diffusion rate in vitro.

Results: The transethosome system formed has a particle size of $167.9 \pm 4.7 \mathrm{~nm}-396 \pm 3.7 \mathrm{~nm}$ with a potential zeta value $(-) 49.54 \pm 1.77 \mathrm{mV}-(-)$ $59.05 \pm 0.95 \mathrm{mV}$, polydispersion index $0.0 \%-57.1 \%$ and entrapment efficiency of $83.76 \%-93.75 \%$. The diffusion rate of F1 and F3 followed the Higuchi kinetics model, while F2 and F4 followed zero-order kinetics and the Korsmeyer-Peppas kinetics.

Conclusion: The combination of tween 60 and span 60 could form a nano-sized transethosome of curcumin. Diffusion rate testing results show that using a surfactant combination can increase the diffusion rate of curcumin, where there is a significant difference between each formula ( $<<0.05$ ).

Keywords: Curcumin, Transethosome, Surfactant, Physical properties, Diffusion rate

(C) 2021 The Authors. Published by Innovare Academic Sciences PvtLtd. This is an open access article under the CC BYlicense (https://creativecommons.org/licenses/by/4.0/) DOI: https://dx.doi.org/10.22159/ijap.2021.v13s3.14 Journal homepage: https://innovareacademics.in/journals/index.php/ijap

\section{INTRODUCTION}

Curcumin is a yellow compound in turmeric (Curcuma longa Linn) and has activities such as antimicrobial, antiinflammatory, antioxidant, and anticancer. Curcumin has low solubility in water, is metabolized first by causing its bioavailability to decrease [1]. This problem can be overcome by formulating curcumin into the form of a transethosome delivery system. Transethosome is a lipid vesicle originating from transfersome and ethosome, characterized by high surfactants and ethanol concentration. Surfactant is a component that affects transethosome penetration. Surfactants have a role in elasticity and penetration in the transethosome system [2, 3].

Previous research showed that the transethosome system could increase voriconazole penetration and has a higher penetration rate than the liposome and ethosome system [4]. Shen et al (2015) researched transethosome vesicles technology using a single surfactant tween 60 or span 60 . The study showed that transethosomes could increase penetration rate but produce unstable vesicles [5]. The effect of increasing the penetration rate of drug-using the transethosome system was seeing in the results of research conducted by Garg et al. (2017). In that study, the surfactant used was span 80 with a concentration of $77.64 \%$ and produced a stable vesicle system [6]. However, surfactants with high concentrations can irritate the skin, so it needs a combination of surfactants to reduce irritation to the skin and has expected to increase the vesicle penetration rate.
Surfactants that can enter the phospholipid bilayer are tween 60 and span 60 . Tween 60 and span 60 are nonionic surfactants that can maintain a balance between hydrophilic and lipophilic groups, nontoxic, and, when combined, have low potential to cause hypersensitivity reactions [7]. Therefore, it is necessary to research the effect of using tween 60 and span 60 as surfactants on the physical properties and diffusion rate of curcumin transethosome.

\section{MATERIALS AND METHODS}

\section{Materials}

Curcumin (Gift from Insular Multi Natural, Indonesia), lecithin (Purchased from Sunshine, Indonesia), tween 60 (Purchased from Clorogen, Indonesia), span 60 (Purchased form Clorogen, Indonesia), millipore membrane (Purchased form Asian, Indonesia), ethanol, sodium hydroxide, potassium dihydrogen phosphate (Purchased form Merck, Indonesia).

\section{Methods}

Formulation and production of curcumin transethosome

This research is an experimental study that makes transethosome curcumin with the various surfactant concentration (tween 60 and span 60) and continues to observe the physical properties of the transethosome system. The formula of transethosome curcumin showed in table 1.

Table 1: Formulation of transethosome curcu min

\begin{tabular}{|c|c|c|c|c|c|}
\hline \multirow[t]{2}{*}{ No. } & \multirow[t]{2}{*}{ Material } & \multicolumn{4}{|c|}{ Formula (\%) } \\
\hline & & F1 & F2 & F3 & F4 \\
\hline 1 & Curcumin & 1 & 1 & 1 & 1 \\
\hline 2 & Lechitin & 10 & 10 & 10 & 10 \\
\hline 3 & Tween 60 & - & 2.5 & 3.33 & 1.67 \\
\hline 4 & Span 60 & 5 & 2.5 & 1.67 & 3.33 \\
\hline 5 & Ethanol & 30 & 30 & 30 & 30 \\
\hline 6 & Aquades ad & 100 & 100 & 100 & 100 \\
\hline
\end{tabular}

*Each batch contains three transethosome in each formula, values are in $\% \mathrm{w} / \mathrm{w}$ 
Transethosome curcumin made using the cold method. Lecithin was dispersed with ethanol at $30^{\circ} \mathrm{C}$ (lipid phase). Surfactants and curcumin are added into the lipid phase and homogenized with a magnetic stirrer at $750 \mathrm{rpm}$ for $5 \mathrm{~min}$ to form a colloidal system. Then add water to the colloidal system little by little in a constant flow, stirring for $5 \mathrm{~min}$ to form a suspension of transethosome curcumin vesicle. The size of the vesicles was reduced by sonication for $15 \mathrm{~min}[3,8]$.

\section{Evaluation of transethosome containing curcumin}

Determination of particle size, polydispersity index, and zeta potential

Determination of particle size distribution, polydispersity index value, and potential zeta value were measured using a particle size analyzer (Delsa Nano Beckman Coulter, USA) [3, 9].

\section{Determination of entrapment efficiency of curcumin}

The determination of curcumin entrapment efficiency was done by centrifugation method at a speed of $4000 \mathrm{rpm}$ for $2 \mathrm{~h}$. Sediment dissolved with ethanol, taken $10.0 \mathrm{ml}$, then put into a $100.0 \mathrm{ml}$ measuring flask. Ethanol is added to the measuring flask boundary line. The solution was measured with a UV/Vis spectrophotometer (Shimadzu, Japan) at a wavelength of $425.5 \mathrm{~nm}$. The concentration of absorbed curcumin obtained converted to a unit of weight, and the percent entrapment efficiency calculated using the formula [10]:

$\%$ Entrapment efficiency

$$
=\frac{\text { Amount of entrpament curcumin }}{\text { Total curcumin }} \times 100 \%
$$

\section{Transethosome diffusion test}

The diffusion test was carried out using a millipore membrane placed between two parts of the diffusion cell. The receptor compartment was conditioned at $37{ }^{\circ} \mathrm{C}$ by flowing water of the same temperature in a water bath. The receptor compartment filled with phosphate buffer $\mathrm{pH} 7.4$ and ethanol as much as $5 \%$ to $150 \mathrm{ml}$, then $1 \mathrm{ml}$ of the test sample applied to the membrane surface. Samples were taken $5 \mathrm{ml}$ at interval times for $8 \mathrm{~h}$. Every sampling was replaced by phosphate buffer $\mathrm{pH} 7.4$, with the addition of $5 \%$ ethanol. Absorption was measured at a wavelength of $421.0 \mathrm{~nm}$. The absorbance value obtained was entered into the linear regression equation to find the diffused percent. Then a curve is made between percent diffused with time [11].

\section{Analysis of diffusion rate kinetics model}

The equation line regression linear for each diffusion rate kinetics was made by zero-order kinetics, first-order kinetics, Higuchi model, and Korsmeyer-Peppas model [12,13].

\section{RESULTS AND DISCUSSION}

The particle size distribution and potential zeta value are the most important physical properties of the transethosome. Transethosome is a lipid-based delivery system that is involved in the nanoparticle delivery system. The nanoparticle delivery system is a delivery system that has a particle size of 1-1000 $\mathrm{nm}$ [14].

The results obtained from this test showed in table 2 . Table 2 showed the average transethosome curcumin particle size of each formula, still in the nanometer criteria (1-1000 nm). This result proves the formula and conditions for making transethosome curcumin produce vesicles with nanometer size with polydispersion percent values 0.0-57.1. The polydispersion index value is a parameter that shows the particle size distribution of the dispersion system. The smaller the polydispersion index value, indicate more homogeneous the system's particle size [15].

Table 2: Test results of the particle size, polydipersion index and zeta potential of transethosome curcu min

\begin{tabular}{llll}
\hline Formula & Test result & & \\
\cline { 2 - 4 } & Particle size (nm) & Polydispersion (\%) & Zeta potential (mV) \\
\hline F1 & $350.4 \pm 6.7$ & 0.0 & $-52.54 \pm 0.93$ \\
F2 & $263.4 \pm 2.4$ & 57.1 & $-49.54 \pm 1.77$ \\
F3 & $396.0 \pm 3.7$ & 0.0 & $-50.10 \pm 0.52$ \\
F4 & $167.9 \pm 4.7$ & 57.1 & $-59.05 \pm 0.95$ \\
\hline
\end{tabular}

*All values were expressed as $(\mathrm{Avg} \pm \mathrm{SD}, \mathrm{n}=3)$ observations

Zeta potential is an important parameter for characterizing nanoparticles, aimed at predicting the stability of colloid solutions. Nanoparticles with potential zeta values above (+/-) 30 $\mathrm{mV}$ should be showed to be stable because surface charges prevent particle aggregation $[15,16]$. The potential values obtained from each of these formulas are-52.54 $\pm 0.93 \mathrm{mV} ;-49.54 \pm 1.77 \mathrm{mV}$; $50.10 \pm 0.52 \mathrm{mV} ;-59.05 \pm 0.95 \mathrm{mV}$. These results showed that each of the transethosome formulae is stable because the values of zeta potential obtained above the value of $-30 \mathrm{mV}$, so the possibility of smaller particle aggregation.
The entrapment efficiency value of curcumin showed in fig. 1. The results showed that curcumin entrapment efficiency was still above $80 \%$, so it was concluded that transethosome could entrap curcumin quite well. The entrapment efficiency value also shows the use of a combination of surfactants can increase the entrapment efficiency, where the entrapment efficiency of F2 with a ratio of Tween and Span 1:1 (F2) was the system with the highest absorption efficiency. These results following the results of research conducted by Lv et al., where the results obtained indicate that the combination of tween-span nonionic surfactants will increase entrapment efficiency [17].

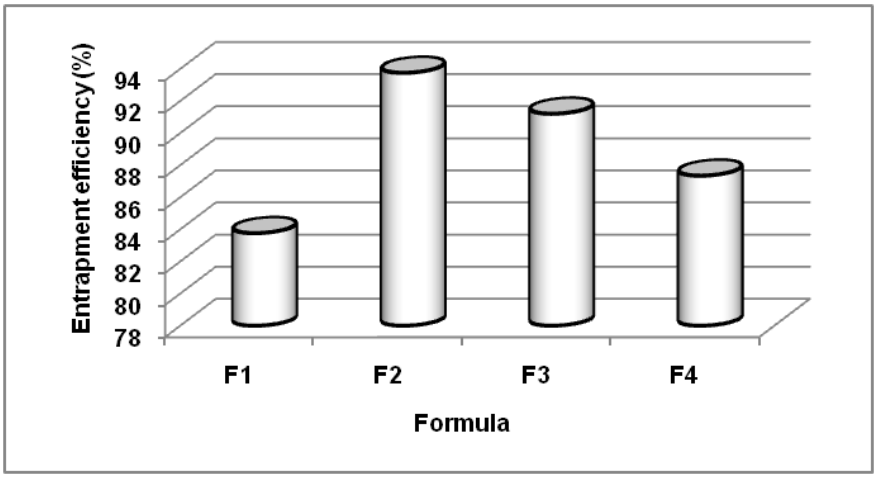

Fig. 1: Percentage value of entrapment efficiency of curcumin $(\operatorname{Avg} \pm S D, n=3)$ 
The cumulative amount of curcumin diffused through the millipore membrane of F1, F2, F3, and F4 for 8 h. The cumulative amount of curcumin showed that the surfactant combination provides better penetration ability than a single surfactant. Based on these results, the highest amount of diffused curcumin was at F4 with a ratio of tween 60 and span 60 (2:1). This result was influenced by particle size. The particle size of F4 is $167.9 \pm 4.7 \mathrm{~nm}$. The smaller the particle size, the greater the surface area, causing rapid drug release [18]. Based on the cumulative amount of diffused curcumin, it could calculate the diffused curcumin cumulative presentation of each formula was $23.02 \pm 2.12 \%, 33.11 \pm 2.4 \%, 24.85 \pm 0.5 \%, 93.77 \pm 0.29 \%$. The transethosome diffusion test curcumin results can then be analyzed to determine the drug release mechanism from the transethosome system (fig. 2).

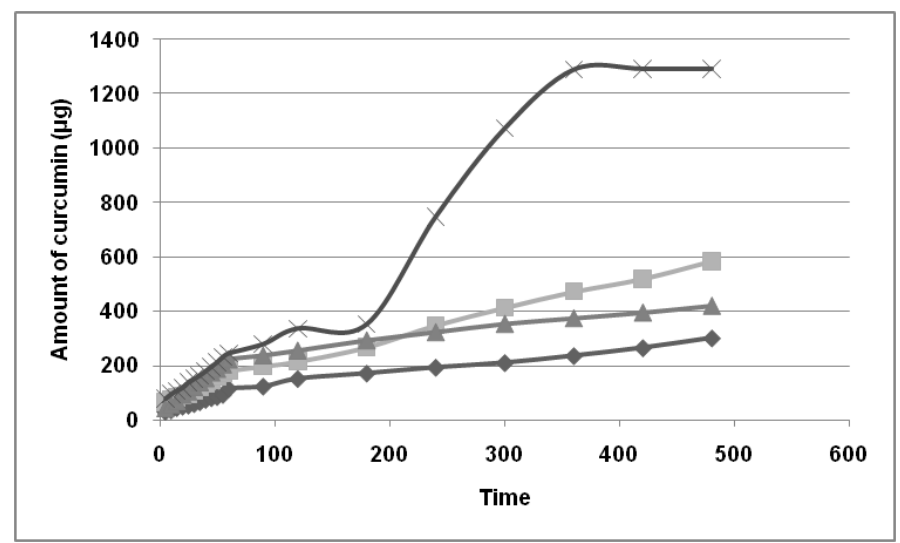

Fig. 2: Diffused cumulative amount of curcumin (F1 (- -$)$; F2 (-

The mechanism of drug release can know by calculating the linearity value of several drug release equations, such as zero-order kinetics (fig. 3), first-order kinetics (fig. 4), Higuchi (fig. 5), and KorsmeyerPeppas (fig. 6) $[13,19,20]$.

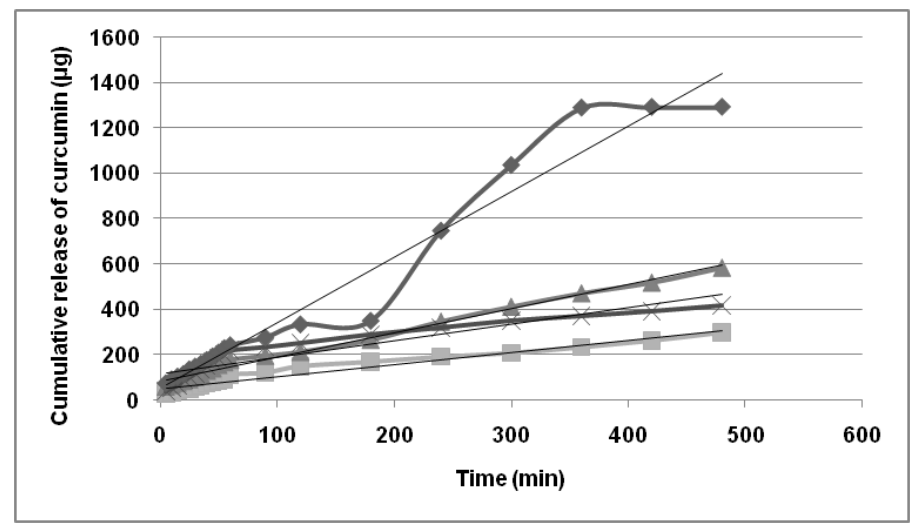

Fig. 3: Zero-order drug release kinetic (F1 (- - ); F2 (- A); F3 (-x-); F4 (-४-))

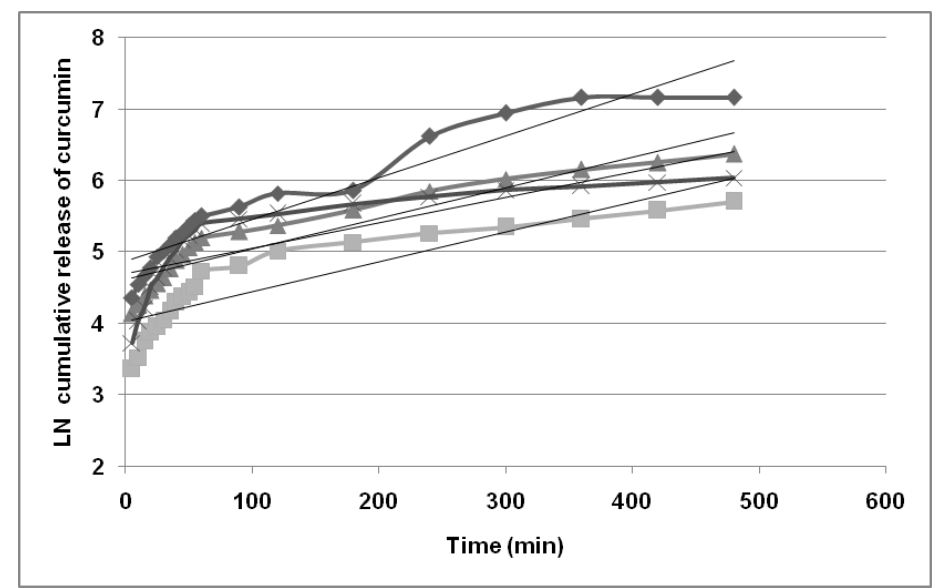

Fig. 4: First-order drug release kinetic (F1 (-); F2 (- A); F3 (-x-); F4 (-४-)) 


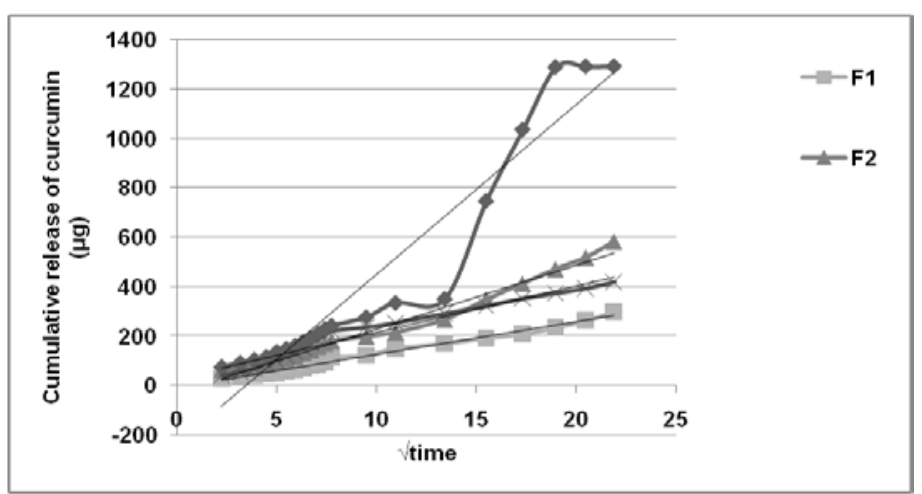

Fig. 5: Higuchi model of drug release kinetic (F1 (-E); F2 (-A); F3 (-x-); F4 (-৬-))

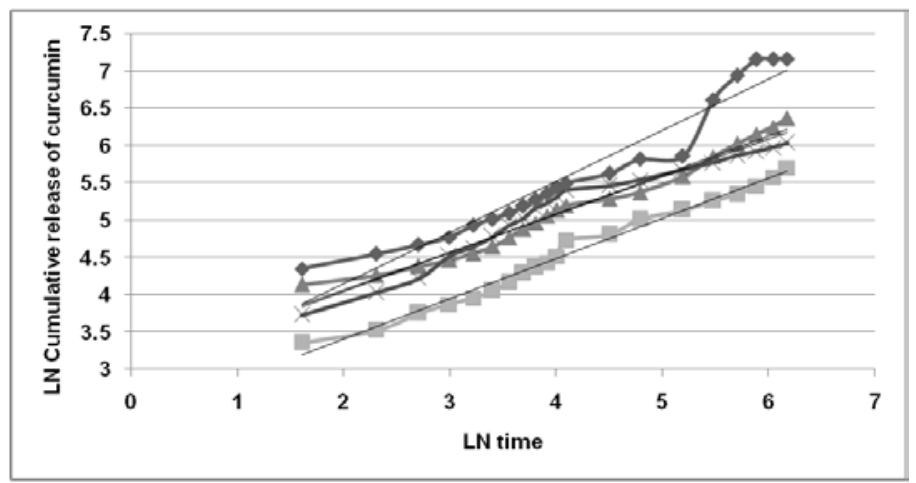

Fig. 6: Korsmeyer-peppas model of drug release kinetic (F1 (- D); F2 (-A); F3 (-x-); F4 (-४-))

The results of the analysis of drug release mechanisms showed in table 3. The highest coefficient (R) in the table shows that the diffusion rate kinetics in F1 and F3 follows the Higuchi kinetics model. Drug release that follows the Higuchi kinetics model illustrates drug release affected by the time $[19,20]$. The release kinetics of F2 follows zero-order kinetics with a value of $\mathrm{R}=$ 0.9942. The kinetics of zero-order release describes the release of drugs slowly and always constant over time. Increased drug concentration is directly proportional to time. The kinetics of the F4 release followed the Korsmeyer-Peppas kinetics $(R=0.9872)$ with an $n$ value of 0.1484 . The value of $n$ obtained is lower than that set by Ritger and Peppas, which is $<0.45$. The low value of $n$ is likely due to the large size and erosion distribution [19]. The value of $n$ obtained can determine that the process occurs through the Fickian diffusion mechanism $[13,20]$. In Fickian diffusion, the rate of release is independent of the drug concentration [18].

Table 3: Curcumin transethosome diffusion rate kinetics*

\begin{tabular}{|c|c|c|c|c|c|}
\hline \multirow[t]{2}{*}{ Formula } & \multirow[t]{2}{*}{ Parameter } & \multicolumn{4}{|l|}{ Diffusion rate kinetics } \\
\hline & & Zero-order (t, Qt/Qo) & First-order one (t, In Qt/Qo) & Higuchi $(\sqrt{t}, Q t / Q o)$ & Korsmeyer-peppas $(\ln \mathrm{t}, \ln \mathrm{Qt} / \mathrm{Qo})$ \\
\hline \multirow[t]{3}{*}{ F1 } & $\mathrm{R}$ & 0.9776 & 0.8837 & 0.9948 & 0.6698 \\
\hline & $\mathrm{k}$ & 0.5383 & 0.0042 & 13.3708 & 37.9701 \\
\hline & $\mathrm{n}$ & - & - & - & 0.1111 \\
\hline \multirow[t]{3}{*}{ F2 } & $\mathrm{R}$ & 0.9942 & 0.9295 & 0.9902 & 0.9802 \\
\hline & $\mathrm{k}$ & 1.0682 & 0.0043 & 25.9698 & 88.5617 \\
\hline & $\mathrm{n}$ & - & & . & 0.1066 \\
\hline \multirow{3}{*}{ F3 } & $\mathrm{R}$ & 0.9256 & 0.7887 & 0.9944 & 0.8858 \\
\hline & $\mathrm{k}$ & 0.8309 & 0.0036 & 12.9101 & 67.6806 \\
\hline & $\mathrm{n}$ & - & & . & 0.0977 \\
\hline \multirow[t]{3}{*}{$\mathrm{F} 4$} & $\mathrm{R}$ & 0.9676 & 0.9443 & 0.9532 & 0.9872 \\
\hline & $\mathrm{k}$ & 2.7019 & 0.0057 & 13.3708 & 66.1947 \\
\hline & $\mathrm{n}$ & - & - & - & 0.1484 \\
\hline
\end{tabular}

*All values were expressed as a summary of the observations

\section{CONCLUSION}

The combination of tween 60 and span 60 as a surfactant could form a nano-sized transethosome of curcumin with an entrapment efficiency above $80 \%$, and diffusion rate testing results show that the use of a surfactant combination can increase the diffusion rate of curcumin.

\section{FUNDING}

The research was funded by the university research institute, Lembaga Penelitian dan Pengembangan (Lemlitbang) Universitas Muhammadiyah Prof. DR. HAMKA.

\section{AUTHORS CONTRIBUTIONS}

All the authors contributed equally.

\section{CONFLICT OF INTERESTS}

Declared none

\section{REFERENCES}

1. Jantarat C. Bioavailability Enhancement Techniques of Herbal Medicine: A Case Example of Curcumin. International Journal of Pharmacy and Pharmaceutical Sciences 2012;5 Suppl 1:493-500. 
2. Ibrahim MA, Yusrida D, Nurzalina AKK, Reem AA, Arshad AK. Ethosomal Nanocarriers The Impact of Constituents and Formulation Techniques on Ethosomal Properties, In vivo Studies, and Clinical Trials. International Journal of Nanomedicine 2016;11:2281-8.

3. Shaji J, Bajaj R. Transethosomes: A New Prospect for Enhanced Transdermal Delivery. International Journal of Pharmaceutical Sciences and Research 2018;9 Suppl 7:2681-5

4. Song CK, Balakrishnan P, Shim CK, Chung SJ, Chong S, Kim DD. A Novel Vesicular Carrier, Transethosom, for Enhanced Skin Delivery of Voriconazole: Characterization and In vitro/In vivo Evaluation. Colloids and Surface B: Biointerfaces 2012;92:299-304.

5. Shen S, Liu SZ, Zhang YS, Du MB, Liang AH, Song LH, Zu GY. Compound Antimalarial Ethosomal Cataplasm: Preparation, Evaluation, and Mechanism of Penetration Enhancement. International Journal of Nanomedicine 2015;10:4249-4253.

6. Garg V, Singh H, Bhatia A, Raza K, Singh SK, Singh R, Sarwar B. Systematic Development of Transethosomal Gel System of Piroxicam: Formulation Optimization, In vitro Evaluation, and Ex Vivo Assessment. AAPS PharmSciTech 2017;18 Suppl 1:58-71.

7. Rowe RC, Sheskey PJ, Marian E Quinn (Ed.). Polysorbate. In Handbook of Pharmaceutical Excipients, 6th Ed. London: Pharmaceutical Press; 2009. p. 549-553,675-678.

8. Abdulbaqi MI, Darwis Y, Khan NA, Assi RA, Khan AA. Ethosomal Nanocarriers: The Impact of Constituents and Formulation Techniques on Ethosomal Properties, In vivo Studies, and Clinical Trials. International Journal of Medicine 2016; 11:2279-2304.

9. Ratnasari D, Anwar E. Karakterisasi Nanovesikel Transfersom sebagai Pembawa Rutin dalam Pengembangan Sediaan Transdermal. Jurnal Farmamedika 2016;1 Suppl 1:12-18.

10. Chen Z, Xia Y, Liao S, Huang Y, Li Y, He Y, Tong Z, Li B. Thermal Degradation Kinetics Study of Curcumin with Nonlinear Methods. Food Chemistry 2014;155:81-86.
11. Wulandari AD, Novianti A, Andika M, Amalia A. Profil Difusi Transethosome Kurkumin dalam Sediaan Gel yang Menggunakan Karbormer 934 sebagai Pembentuk Gel. Journal of Current Pharmaceutical Sciences 2019;3 Suppl 1:180-5.

12. Dash S, Murthy PN, Nath L, Chowdhury P. Review: Kinetic Modeling on Drug Release from Controlled Drug Delivery Systems. Acta Poloniae Pharmaceutica-Drug Release 2010;67 Suppl 3:217-223.

13. El-Nashar DE, Rozik NN, Soliman AM, Helaly F. Study the release kinetics of curcumin released from PVA/curcumin composites and its evaluation towards hepatocarcinoma. Journal of Applied Pharmaceutical Science 2016;6 Suppl 07:67-72

14. Das S, Chaudhury A. Recent Advances in Lipid Nanoparticle Formulation with Solid Matrix for Oral Drug Delivery. AAPS PharmSciTech 2011;12 Suppl 1:62-76.

15. Anonim. Analysis Software and Reference Kit Beckman Coulter Delsa Nano. USA: Beckman Coulter; 2015.

16. Mohanraj VJ, Chen Y. Nanoparticles-A Review. Tropical Journal of Pharmaceutical Research 2006;5 Suppl 1:561-573.

17. Lv G, Wang F, Cai W, Zhang X. Characterization of the Addition of Lipophilic Span 80 to The Hydrophilic Tween 80-Stabilized Emulsions. Colloids Surf A Physicochem 2014;447:8-13.

18. Sinko, PJ. Diffusion. In: Martin's Physical Pharmacy and Pharmaceutical Sciences, 6th Edition. New Jersey: Lippincott William and Wilkins, a Wolter Kluwer business; 2011. p. 223-57.

19. Martinez A, Arana P, Fernandez A, Olmo R, Teijon C, Blanco MD. Synthesis and Characterisation of Alginate/Chitosan Nanoparticles as Tamoxifen Controlled Delivery Systems. Journal of Microencapsulation 2013;30:398-408.

20. Unagolla JM, Jayasuriya AC. Drug Transport Mechanisms and In vitro Release Kinetics of Vancomycin Encapsulated ChitosanAlginate Polyelectrolyte Microparticles as a Controlled Drug Delivery System. Eur J Pharm Sci 2018;144:199-209. 